\title{
INFRAESTRUTURA VERDE EM ÁREA DE MANANCIAL: UM ESTUDO PARA A REPRESA BILLINGS
}

GREEN INFRASTRUCTURE IN A WATER SOURCE AREA:

A STUDY FOR THE BILLINGS DAM

\begin{abstract}
RAMón STOCK BonzI
Mestre em Arquitetura e Urbanismo pela FAUUSP, na área de concentração Paisagem e Ambiente. Especialista em Meio Ambiente e Sociedade (FESPSP) e em Arquitetura da Paisagem (SENAC). rsb@usp.br

Oliver de LUCCIA

Arquiteto e pesquisador do Grupo Metrópole Fluvial (FAU-USP) . Graduado em Arquitetura e Urbanismo pela Universidade de São Paulo e mestrando na mesma instituição.

oliver.luccia@usp.br

Mayra Menossi Almodova

Graduação em Arquitetura e Urbanismo na Universidade Estadual Paulista Júlio de Mesquita Filho (FCT-UNESP). mayra_almodova@yahoo.com.br
\end{abstract}

\section{RESUMO}

Embora sirva ao abastecimento de água desde a década de 1950 e seja protegida por leis desde a década de 1970, a represa Billings teve seu entorno ocupado de maneira inadequada, o que comprometeu significativamente a qualidade de suas águas. Com a "crise hídrica" de 2014-2015 tornou-se evidente a sua importância estratégica já que possui potencial para triplicar a população atendida. Para que isso se torne viável é preciso evitar que o reservatório continue sendo degrada pelo despejo de esgoto não tratado e pela carga de poluição difusa trazida pelo escoamento superficial das chuvas em áreas urbanizadas. Este trabalho investiga como a infraestrutura verde pode ajudar a conciliar a ocupação do entorno da Billings com a produção de água de boa qualidade. Apresenta um método, diretrizes e ensaio projetual para uma sub-bacia do Ribeirão Cocaia, curso d'água afluente da Billings.

Palavras-chave: represa Billings; infraestrutura verde; mananciais urbanos; ribeirão Cocaia; abastecimento de água. 


\begin{abstract}
Although it is used as a source of water supply since the 1950s and has been protected by legislation since the 1970s, the Billings Dam has had its surroundings inadequately occupied, which has significantly compromised the quality of its waters. With the "water crisis" during 2014-2015, its strategic importance became evident since it has the potential to triplicate the population served. For this to be feasible it is necessary to avoid that the reservoir continues being degraded by the discharge of untreated sewage and by the diffuse pollution brought by the surface runoff of the rains of urbanized areas. This article investigates how the green infrastructure can help reconcile the occupation of the Billings Dam surroundings with the production of potable water. It presents a method, guidelines and a design essay for a sub-basin of Ribeirão Cocaia, an affluent of Billings Dam.
\end{abstract}

Keywords: Billings Dam; green infrastructure; urban water sources; Cocaia Stream; water supply.

\title{
INTRODUÇÃO
}

O abastecimento de água potável está entre os maiores desafios que se colocam para a região metropolitana de São Paulo, como bem evidenciou a chamada "crise hídrica" de 2014 e 2015. Embora o episódio tenha desencadeado amplo debate público, a ideia de que se tratava de uma crise, e portanto de evento excepcional, fora da normalidade, escamoteou o fato de que o abastecimento de água sempre foi um problema para São Paulo. Em 1870, por exemplo, esse já era o principal problema da cidade, embora ela contasse então com apenas 50 mil moradores (lamamura,2006, p.52).

Ainda que seja possível argumentar que o problema crônico de abastecimento de São Paulo se deve ao fato de que a região possui baixa disponibilidade hídrica natural por se localizar no alto curso do rio Tietê (Silva; Porto, 2003), a histórica dificuldade para prover o serviço sinaliza a existência de outras causas para além de determinismos geográficos e explosões demográficas.

Neste sentido destaca-se o fato de que São Paulo tem crescido sem conferir a devida importância à base natural sobre a qual se assenta. No que tange aos recursos hídricos, as operações típicas da urbanização paulistana - supressão da cobertura vegetal, impermeabilização maciça do solo e alteração radical de rios e córregos - modificaram 
sobremaneira o ciclo hidrológico, desencadeando inundações, mudanças nos padrões de precipitação, ilhas de calor e piora na qualidade do ar e das águas superficiais.

Outro fator que cria uma série de dificuldades para o abastecimento público paulistano é que a cidade tem sido planejada, projetada e gerida dentro de uma lógica setorial. Desta maneira, as infraestruturas competem entre si por financiamento, recursos naturais, espaço físico e prestígio junto à sociedade e administração pública. Nessas batalhas infraestruturais, frequentemente um dos sistemas torna-se obsoleto ou perde grande parte de sua capacidade de operação.

O presente trabalho se debruça sobre uma área estratégica para o abastecimento de São Paulo e que apresenta os problemas e as dinâmicas recém elencadas: a represa Billings.

Criada originalmente como reservatório da usina hidrelétrica Henry Borden, teve seu uso alterado para o abastecimento público, reduzindo assim a geração de energia. Posteriormente, a função de abastecimento público foi limitada devido à poluição decorrente da ocupação clandestina de seu entorno e de sua integração ao sistema de macrodrenagem da cidade.

No auge da chamada "crise hídrica" o reservatório ganhou do governador do estado o status de "caixa d'água" da cidade, mas o seu nível de poluição gerou dúvidas sobre a viabilidade financeira do tratamento dessas águas para fins de abastecimento.

Tendo em vista os limites evidentes de se continuar planejando, projetando e gerindo a infraestrutura da maneira como tem sido feita, o presente estudo investiga estratégias alternativas capazes de enfrentar o grave quadro de escassez hídrica que ameaça a região metropolitana de São Paulo (RMSP).

A pesquisa adota como referencial teórico a infraestrutura verde, entendida aqui como a noção de que a paisagem é capaz de fornecer serviços ecossistêmicos fundamentais para o bom funcionamento da cidade. A metodologia do trabalho abarca três momentos diferentes. Primeiramente, a pesquisa bibliográfica reconstitui a formação da represa Billings e descreve os processos que levaram à ocupação dos mananciais e os problemas daí decorrentes.

Para a caracterização do recorte espacial selecionado, uma sub-bacia do Ribeirão Cocaia, foi feito o levantamento cartográfico da área, visitas de campo de caráter exploratório e consulta a planos existentes. A articulação destes procedimentos permitiu a produção de mapas temáticos, a descrição detalhada da área e uma primeira aproximação no que diz respeito à identificação de problemas e potencialidades locais. 
O trabalho culmina com a aplicação conceitual da infraestrutura verde na área de estudo. Como etapa prévia ao ensaio projetual propriamente dito, foi realizada a compartimentação do relevo conforme metodologia proposta por Schutzer $(2004,2012)$ e adaptada por Bonzi (2015a, 2015b) para o contexto da infraestrutura verde. Este procedimento permitiu maior aprofundamento na identificação dos problemas, mas, sobretudo, dos potenciais encerrados na base biogeofísica local.

O aproveitamento destes potenciais até então negligenciados constituiu, em si mesmo, a base real para o projeto. Este demonstra que em grande parte é possível harmonizar a ocupação consolidada em áreas de manancial com a produção de água de boa qualidade. Trata-se, portanto, de uma alternativa à ampla remoção populacional da área de mananciais pretendida pela nova gestão municipal ${ }^{1}$.

\section{REPRESA BILLINGS - DA GERAÇÃO DE ENERGIAAO ABASTECIMENTO DE ÁGUA}

A Billings é o maior reservatório da região metropolitana de São Paulo. Tem $1200 \mathrm{hm}^{3}$ de capacidade de armazenamento, espelho d'água oscilando entre 108 e $127 \mathrm{~km}^{2}$ e área de drenagem de $582,8 \mathrm{~km}^{2}$, o que equivale a $7,3 \%$ da RMSP.

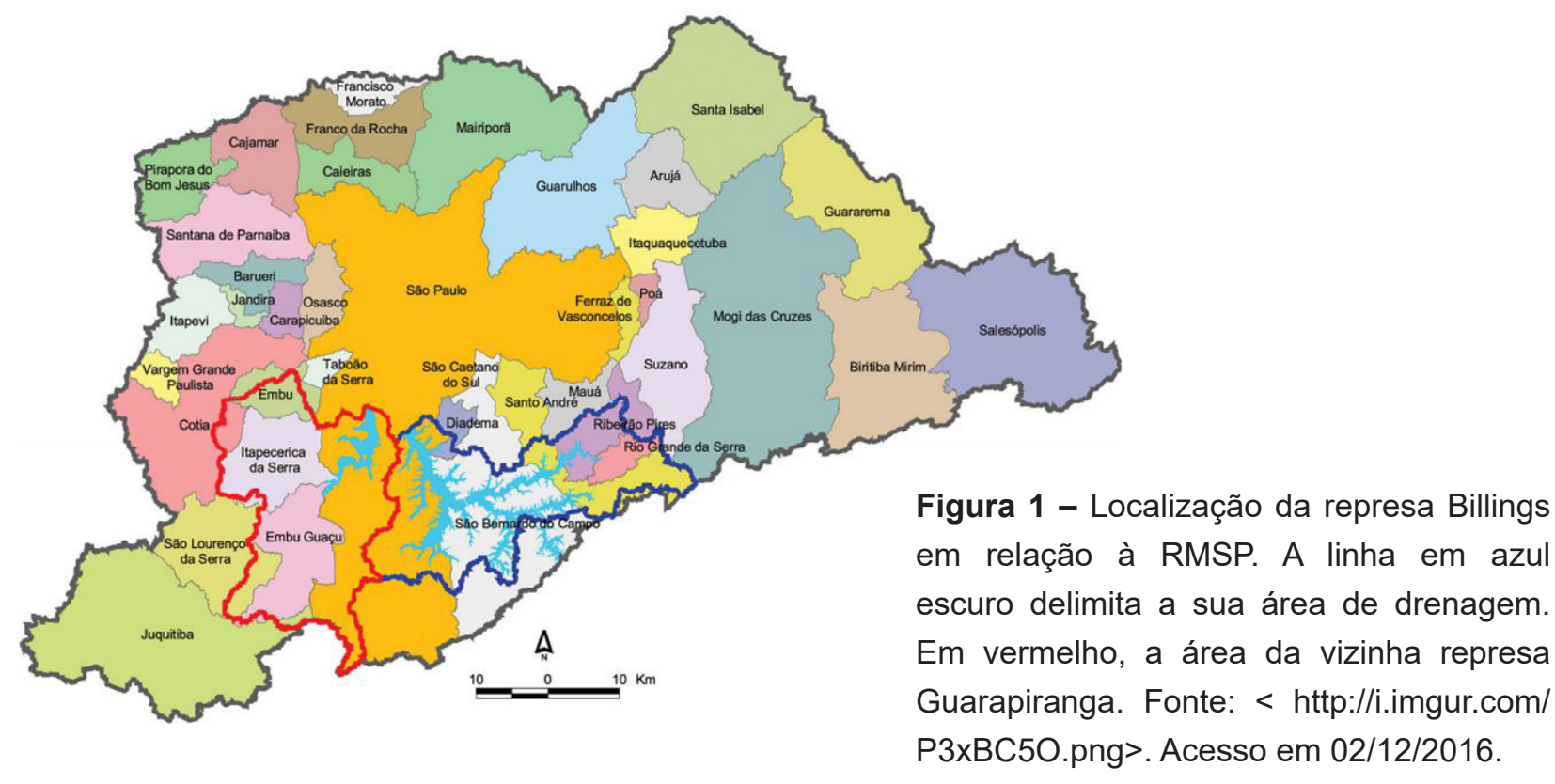

\footnotetext{
1 Ver, por exemplo: < http://www.valor.com.br/politica/4732829/doria-diz-que-nao-vai-tolerar-invasoese-preve-ciclovia-privatizada>. Acesso em 25/11/2016.
} 
O reservatório está localizado no sul da RMSP (ver figura anterior), em domínio de mata Atlântica, estendendo-se por seis municípios (São Paulo, Diadema, São Bernardo do Campo, Sto André, Ribeirão Pires e Rio Grande da Serra). Suas principais cabeceiras estão localizadas na Serra do Mar, onde se registram os maiores índices pluviométricos (da ordem de $3500 \mathrm{~mm} / \mathrm{ano}$ ). À oeste compartilha um divisor de águas com a bacia hidrográfica da represa Guarapiranga.

A Billings tem profundidade média de 25 metros e sua cota máxima é $747,5 \mathrm{~m}$. Apresenta perímetro de $800 \mathrm{~km}$ e vazão natural de $12,5 \mathrm{~m}^{3}$.

Embora hoje seja usado para o abastecimento d'água, o reservatório foi originalmente criado para reforçar a geração de energia da usina hidrelétrica Henry Borden, em Cubatão. A usina foi inaugurada em 1926 e conceitualmente a ideia era tomar partido do desnível de $720 \mathrm{~m}$ da Serra do Mar. Para isso, em 1925 foi feita a transposição do rio Grande, na vertente continental da Serra do Mar, para o rio das Pedras, na vertente oceânica. A inundação da área hoje ocupada pelo reservatório teve início em 1927, com a construção da barragem de Pedreira, que barrou o fluxo do rio Grande rumo ao rio Pinheiros.

Para aumentar a capacidade de geração da hidrelétrica, o rio Pinheiros teve seu curso revertido, passando a receber as águas do rio Tietê, curso d'água do qual era um tributário. A construção das usinas elevatórias de Traição e Pedreira, no final de década de 1930, tornou possível que as águas do Tietê-Pinheiros alimentassem a Billings. A represa passou a servir para o abastecimento público no final da década de 1950, como resposta ao forte crescimento demográfico de São Paulo, notadamente a região do ABC.

\section{DEGRADAÇÃO DO RECURSO HÍDRICO}

O crescimento demográfico acompanhou o crescimento industrial de São Paulo. Devido ao fato de ter sido uma industrialização com baixos salários, um contingente enorme de trabalhadores não possuía renda suficiente para ocupar as áreas de urbanização consolidada, dotadas de habitação e sistemas de infraestrutura.

Sem acesso ao mercado mobiliário legal, restavam então, os cortiços na região central, as áreas periféricas, as encostas e as margens dos córregos, enfim, os espaços negligenciados pelo mercado formal. As áreas de manancial despontaram então como opção habitacional para quem tivesse baixa. 
O poder público, além de não conseguir incrementar a oferta de serviços, habitação e infraestruturas demandada pelo crescimento demográfico de São Paulo, se mostrava incapaz de fiscalizar um território tão grande a fim de inibir a ocupação de áreas não autorizadas. Progressivamente, passou a ser corrompido pelos interesses de um mercado imobiliário ilegal que se formou para lucrar com essa dinâmica.

Um dos resultados desse fenômeno foi a rápida degradação do reservatório Billings.

Embora seja protegida pela Lei dos Mananciais desde a década de 1970, estima-se que cerca de 900 mil pessoas morem em sua área de drenagem. SILVA (2013) informa que há atividades humanas em $27 \%$ da bacia, sendo $20 \%$ podendo ser considerada como área urbana. Em 1982, para viabilizar a continuidade do uso da represa como fonte de água para abastecimento público, foi feito o isolamento físico de um dos seus braços, o do rio Grande, com a construção da barragem Anchieta.

Dado que boa parte de sua ocupação se deu de forma clandestina, por meio de favelas, mas sobretudo, loteamentos irregulares, o manancial encontra-se degradado por receber lançamento de esgoto e a poluição difusa que é carreada pelo escoamento superficial durante as chuvas. Outra fonte de degradação é o recebimento das águas poluídas dos rios Pinheiros, via a reversão do curso d'água. Parcialmente proibida em 1992, ainda acontece para evitar a inundação de áreas na região mais central da capital. Isso limitou a geração de energia da usina Henry Borden a apenas $25 \%$ de sua capacidade instalada.

Tudo isso faz com que apenas uma pequena parte de suas águas seja aproveitada para abastecimento. Atualmente a Billings é responsável pelo abastecimento de 1,3 a 1,6 milhões de pessoas, mas poderia abastecer, segundo o Instituto Socioambiental (ISA), até 4,5 milhões (Capobianco;Whately, 2002). Sua água é tratada pela ETA Rio Grande, que apresentada capacidade de $5 \mathrm{~m}^{3} / \mathrm{s}$.

Mesmo frente à tamanha urgência, o planejamento tecnocrático e setorial não consegue atuar de uma maneira clara para enfrentar a situação. Amparado em leis e políticas públicas que possuem aspectos antagônicos entre si, seus desígnios oscilam entre simplesmente retirar a população da área de mananciais, legalizá-la por meio de regularização fundiária e reurbanização ou levar a lógica da infraestrutura de esgotamento sanitário centralizada para tratar os efluentes a dezenas de quilômetros de onde são gerados.

Seja como for, apesar da poluição da represa Billlings, em 2000 foi construído um 
canal que permite captação do braço Taquacetuba para reforçar a vazão da represa Guarapiranga. A ilustração abaixo sintetiza a cronologia de formação e subsequentes alterações de uso da represa.

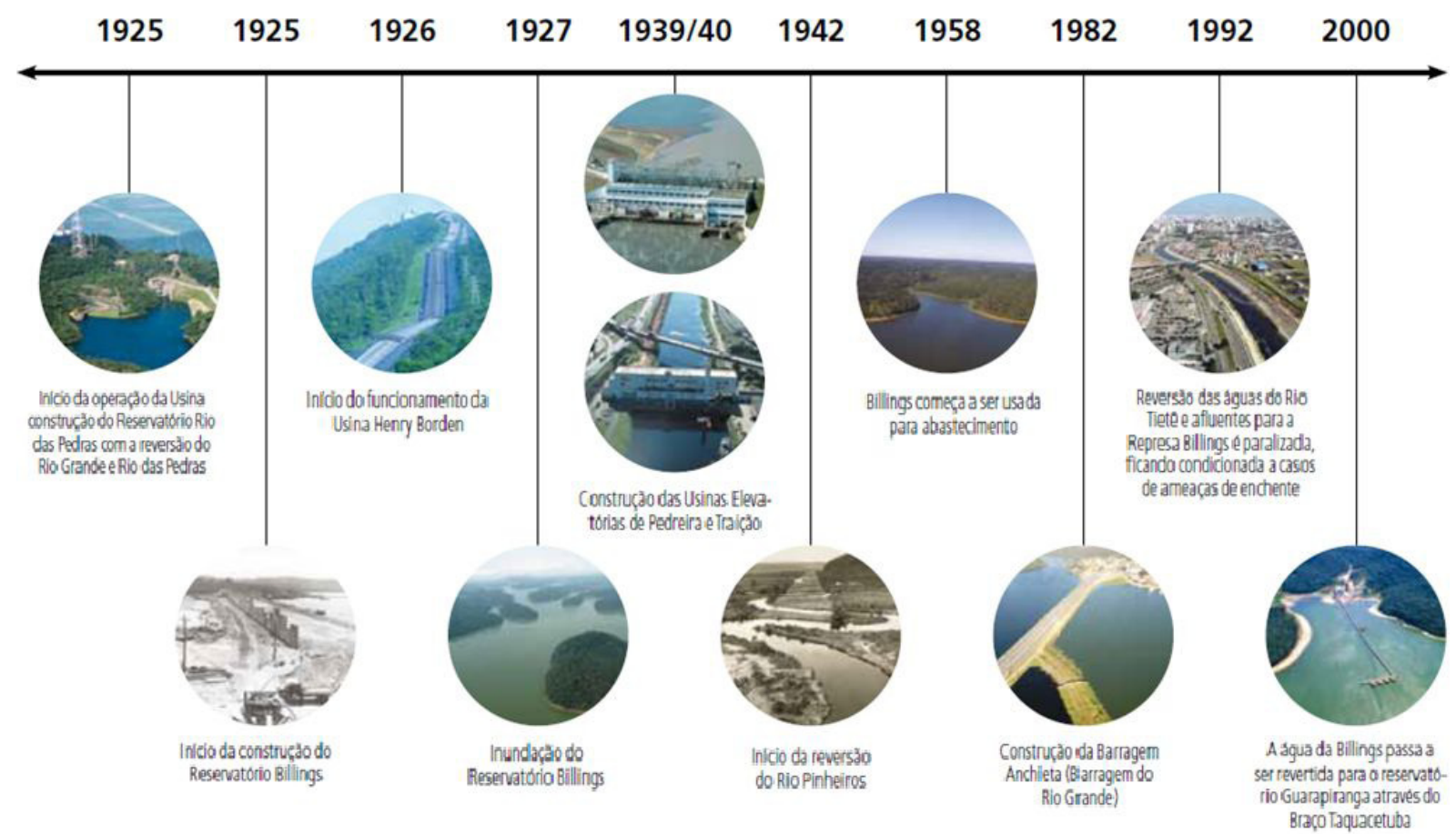

Figura 2-Cronologia da represa Billings indicando os principais marcos na sua formação e alterações de uso. Adaptado de <http://www.ambiente.sp.gov.br/cea/files/2015/06/Cadernos-de-Educa\%C3\%A7\%C3\%A3oAmbiental-Edi\%C3\%A7\%C3\%A3o-Especial-Mananciais-Billings.pdf>. Acesso em 07/12/2016.

\section{A BACIA HIDROGRÁFICA DO RIBEIRÃO COCAIA}

O ribeirão Cocaia, ou córrego Reimberg Cocaia, forma um dos braços da represa Billings. Está localizado na zona sul da cidade de São Paulo, na subprefeitura da Capela do Socorro, em área de proteção de mananciais.

Sua área de drenagem totaliza cerca de $19,3 \mathrm{~km}^{2}$. É possível encontrar afluentes ainda em estado natural (não canalizado), canalizados a céu aberto e ocultos (canalizados de maneira subterrânea), como diferenciados na próxima figura. De acordo com estudo comandado por Bonduki e Ferreira (2006), o comprimento total dos córregos totaliza $43,55 \mathrm{~km}$, tendo $4,8 \mathrm{~km}$ o talvegue principal (p.97).

Do ponto de vista da qualidade das águas, a maior parte de seus córregos estão bas- 
tante poluídos já que nem toda a bacia possui sistema de captação e tratamento de esgoto e a densidade habitacional é elevada. Há assentamentos precários em que os próprios moradores instalaram canos para se livrar de seus efluentes no córrego mais próximo (em alguns casos, na sarjeta mais próxima). E há setores em que o loteador instalou o sistema de coleta de esgoto, mas não providenciou a sua conexão a um sistema de tratamento, de maneira que os efluentes coletados são despejados no curso d'água mais próximo ou diretamente na represa.

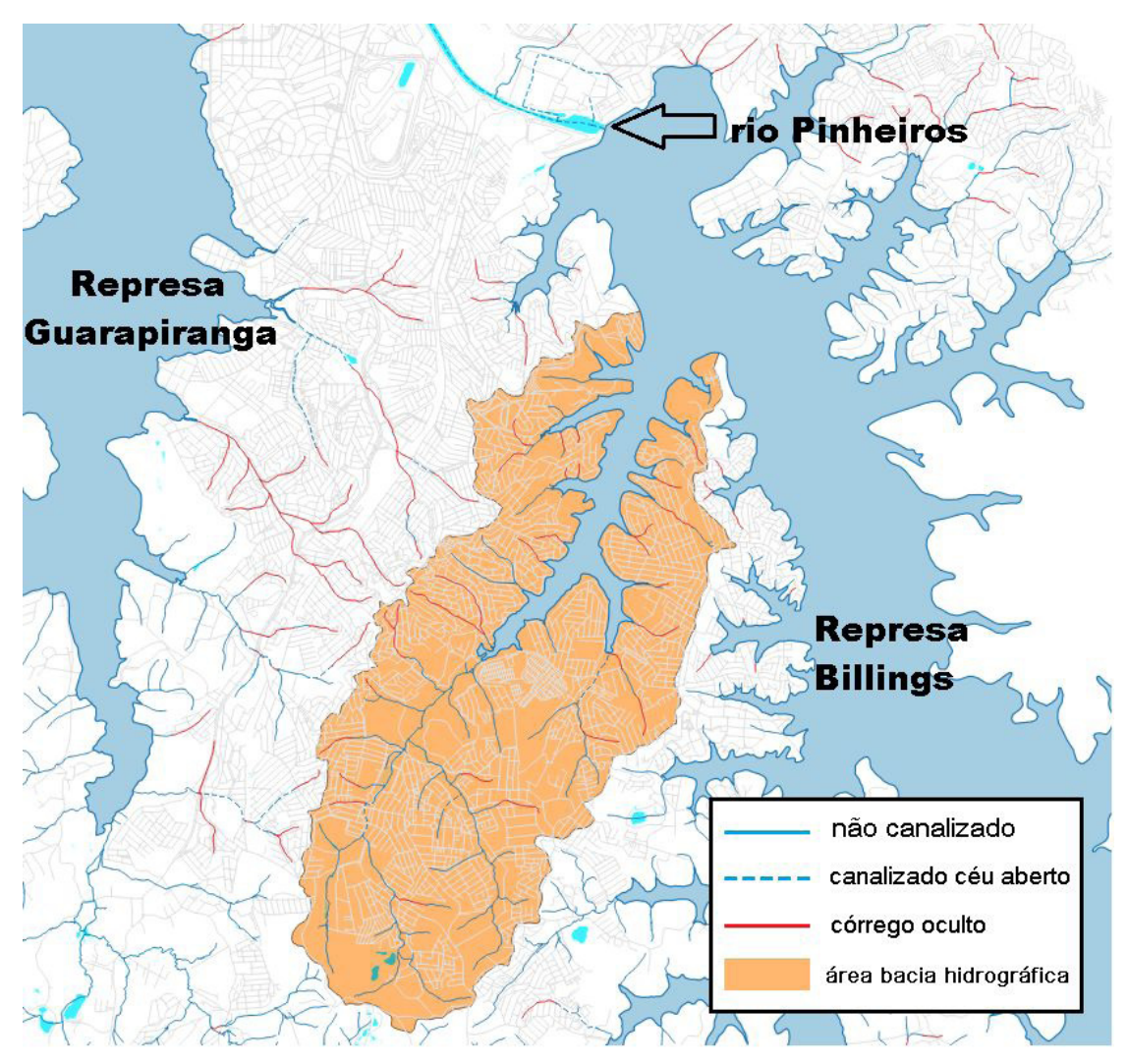

Figura 3 - Hidrografia do Ribeirão Cocaia e arrabaldes com diferenciação tipológica dos cursos d'água. Elaborado a partir de levantamento do GeoSampa.

Outra dinâmica que colabora com a poluição das águas da represa é o escoamento superficial, que tem seu volume consideravelmente incrementado pela impermeabilização da bacia e consequente diminuição dos processos de evapotranspiração e infiltração.

Além do aumento na probabilidade de cheias e inundações, durante as chuvas o escoamento superficial lava as ruas e carrega consigo metais pesados, particulados, fragmentos de pneus e pastilhas de freio, fezes de animais e lixo não coletado ou descartado incorretamente. Esta verdadeira sopa tóxica é muitas vezes mais poluente que o próprio esgoto e alcança os canais rapidamente, sendo conduzida para o corpo da represa Billings. 
Nos córregos mais alterados pelo homem, a situação é ainda mais grave porque nestes canais não há a presença da mata ciliar e da vegetação aquática que poderiam reter e filtrar esses poluentes, melhorando assim a qualidade da água antes que ela chegasse à represa. Quando canalizados de maneira subterrânea, são inviabilizados também os processos de insolação e de ventilação, que também são responsáveis pela depuração da matéria orgânica e consequente melhoria na qualidade da água.

À essa degradação ambiental preocupante, somam-se outros problemas para os habitantes humanos e não-humanos da bacia do Cocaia. Trata-se de uma região densamente ocupada sem infraestruturas em quantidade suficiente, carente de serviços públicos, empregos locais e com poucas áreas verdes públicas minimamente qualificadas para o lazer da população ou para criar refúgios para a biodiversidade.

A região é servida de transportes públicos sobre rodas e trilhos, mas a inexistência de transporte fluvial transforma o braço da represa em estorvo que impõe longos percursos para se locomover de pontos que estão muito próximos fisicamente. Sua ocupação é predominantemente residencial, apresentando áreas de mineração ao sul, junto aos divisores d'água. Há chácaras e remanescentes vegetais distribuídos ao longo da orla da represa e de maneira esparsa em todo o território.

A combinação entre autoconstrução habitacional, declividades acentuadas em sua face oeste e presença de amplos depósitos aluviais sedimentares dota a bacia hidrográfica do Ribeirão Cocaia de setores que merecem atenção do ponto de vista de prevenção de riscos, sobretudo deslizamentos.

A área possui atrativos e diferenciais cênicos, como a presença de uma linha de alta tensão (linhão), pequenos córregos e brejos, além do gigantesco espelho d'água da Billings, que inclusive está em rota de migração de pássaros e já foi muito utilizado para recreação e esportes náuticos. No entanto, a urbanização como vem acontecendo reduz as possibilidades de se contemplar ou usufruir esses cenários, já que esses espaços públicos dotados de grande potencial paisagístico e social ficam confinados nos fundos dos lotes, sem acesso público.

\section{CARACTERIZAÇÃO DA ÁREA DE PROJETO}

A fim de privilegiar a escala do projeto, optamos por escolher uma área pequena, que pudesse comportar tanto uma proposta de planejamento quanto de ensaio arquitetônico. 
Tendo em vista o consenso, tanto entre profissionais dos recursos hídricos quanto entre designers ecologicamente informados, que a unidade de planejamento ideal é a bacia hidrográfica, foi selecionada uma sub-bacia na península leste do Ribeirão Cocaia.

Trata-se de uma área de $0,56 \mathrm{~km}^{2}$. Ela é composta pela somatória das áreas de drenagem de um pequeno córrego e das áreas de contribuição difusa contíguas.

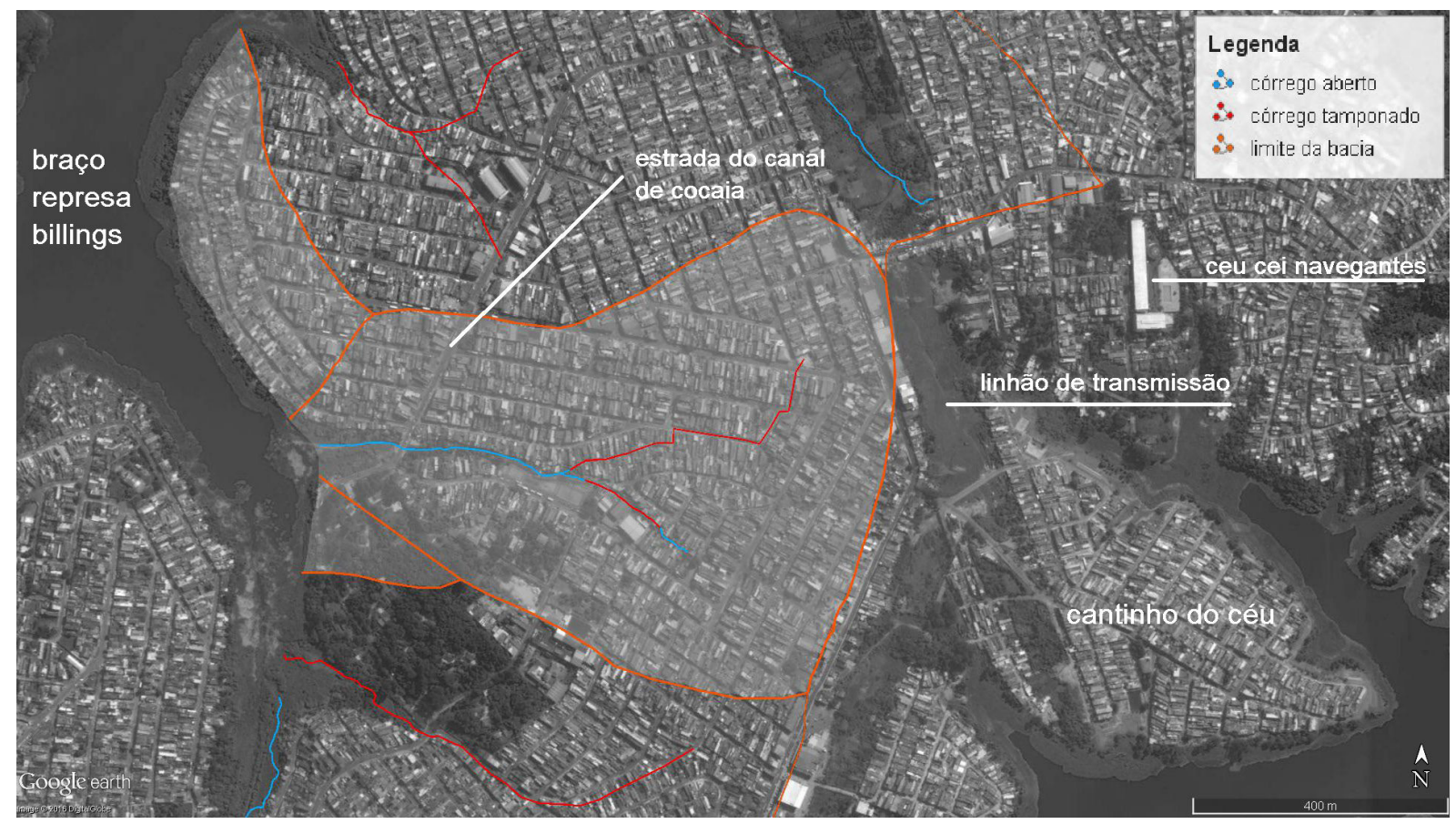

Figura 4 - Área de intervenção com indicação de cursos d'água e suas tipologias, acesso principal e referências geográficas próximas.

Uma vez que a densidade demográfica da região é de 300 habitantes/hectare (Bonduki; Ferreira, 2006, p. 105) estimamos que a população da área seja de 18 mil pessoas (o cálculo agrega uma margem de segurança de 1200 pessoas).

Segundo Bonduki e Ferreira (2006), "em função das restrições da legislação de proteção aos mananciais, a região caracteriza-se por ser um 'bairro dormitório', com baixa oferta de emprego e grande concentração de população jovem" (p.85).

De acordo com dados da Secretaria Municipal de Desenvolvimento Urbano (SMDU) ${ }^{2}$

\footnotetext{
${ }^{2}$ Cadernos das Subprefeituras-Capela do Socorro: Material de apoio para revisão participativa dos planos regionais das subprefeituras". Disponível em <http://gestaourbana.prefeitura.sp.gov.br/ arquivos-prs/>. Acesso em 02/12/2016.
} 
a área tem alta vulnerabilidade social $(29,47 \%$ - dados relativos à toda a Capela do Socorro) e predominância de residências horizontais de baixo padrão.

O comércio se concentra ao longo da rua Demas Zito e da estrada Canal de Cocaia, o acesso principal da área.

O córrego que drena a área é um tributário da represa Billings, sem nome, e não foi canalizado. Ele possui dois pequenos afluentes que foram parcialmente canalizados de maneira subterrânea, como é possível ver na figura anterior.

A sua mata ciliar foi praticamente erradicada e o que não está tomado por edificações foi invadido por braquiária. O mesmo verifica-se na orla da represa. A ausência de vegetação ciliar reduziu a capacidade que a paisagem tem de filtrar a poluição difusa carreada pelo escoamento superficial da água da chuva (o que é tão prejudicial para a qualidade da água quanto a falta de tratamento de esgoto) e ainda colabora com o assoreamento da represa, diminuindo a sua capacidade de armazenamento.

A exemplo do que se verifica em toda a bacia do Cocaia, apesar da proximidade da reservatório e da importância da Billings para o abastecimento público de São Paulo, há vastos setores do território sem esgotamento sanitário adequado. Durante visita de campo realizada em outubro de 2016, foi possível identificar situações em que o esgotamento inadequado é feito por ligações clandestinas improvisadas pelos próprios moradores, como ilustra a figura a seguir.

No entanto a análise de bases da própria prefeitura de São Paulo ${ }^{3}$ mostra que esta não é a principal tipologia de contaminação do reservatório.

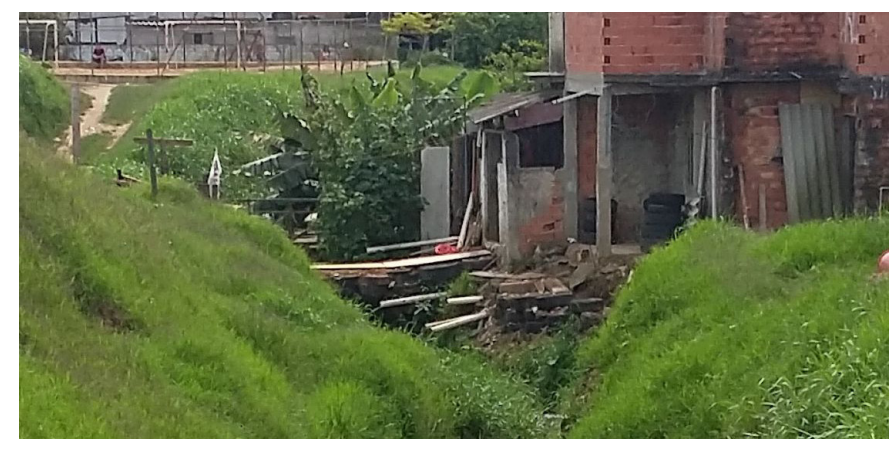

Figura 5 - Esgoto lançado no afluente do Ribeirão Cocaia por meio de ligações clandestinas.

3 Consultar "mapa 7", na seção "arquivos do Plano Diretor", no site < http://gestaourbana.prefeitura. sp.gov.br/marco-regulatorio/plano-diretor/arquivos/>. Acesso em 01/12/2016. 
Conforme pode-se observar no mapa a seguir, há amplos setores da sub-bacia que não possuem esgotamento sanitário adequado. Considerável parte das habitações aí localizadas estão centenas de metros distantes do corpo d'água mais próximo, o que inviabiliza o seu descarte direto, improvisado pelos próprios moradores.

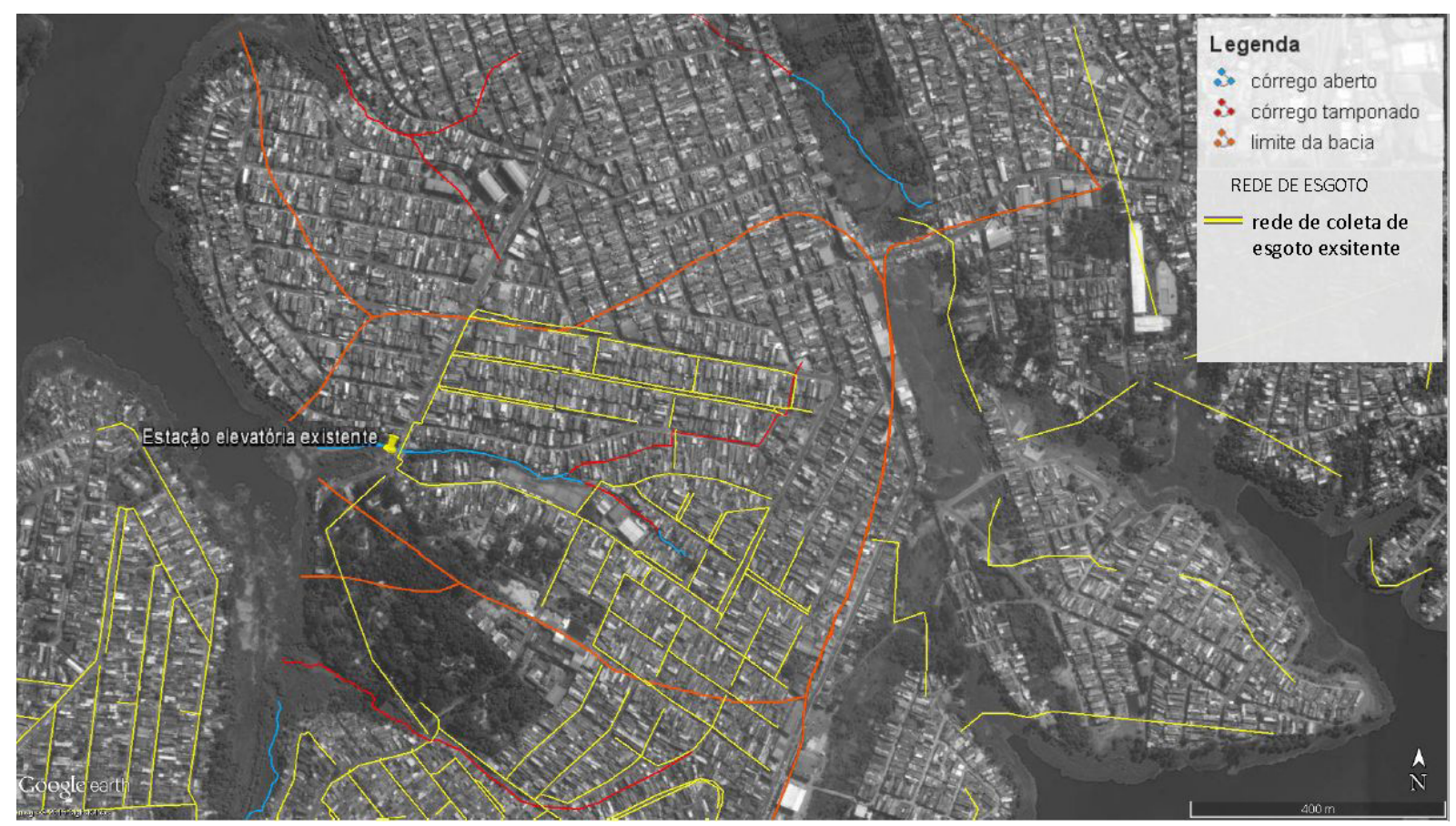

Figura 6 - Rede coletora de esgoto existente, como indicação de estação elevatória. Elaborado a partir de bases de <http://gestaourbana.prefeitura.sp.gov.br>.

Durante a visita de campo não foi encontrada a situação tão comum em assentamentos subnormais de se descartar o esgoto na própria rua. A área também é demasiadamente adensada para contar com fossas sépticas. O que significa que a tipologia de esgotamento inadequado predominante nesta sub-bacia é a da rede coletora implantada durante o loteamento irregular da área. Esta, ao invés de estar conectada a um coletor tronco existente, foi ligada diretamente à represa ou ao pequeno afluente do Cocaia, poluindo assim o manancial.

Já a rede coletora que está regularizada destina os efluentes para uma estação elevatória de esgoto, localizada na foz do afluente do Cocaia com o braço da represa Billings. Daí é feito um bombeamento para um coletor tronco que está conectado ao interceptor de esgoto da marginal Pinheiros. O destino final é a ETE Barueri, a dezenas de quilômetros, em outra cidade. Embora esteja às margens da Billings, o abastecimento de água potável é feito pelo sistema Guarapiranga. 
Há carência de áreas verdes qualificadas e o espaço mais próximo capaz de oferecer opções de lazer ao ar livre é o parque linear do Cantinho do Céu, criado em 2012 com a reurbanização de comunidades subnormais do Grajaú, na outra vertente da península onde se localiza a sub-bacia escolhida para este estudo. As áreas estão separadas pela linha de transmissão de energia em alta tensão (linhão).

O novo plano diretor estratégico (PDE) da cidade de São Paulo (Lei 16.050/2014) e o novo zoneamento dele decorrente (parcelamento, uso e ocupação do solo -LPUOS) preveem algumas importantes diretrizes para a região.

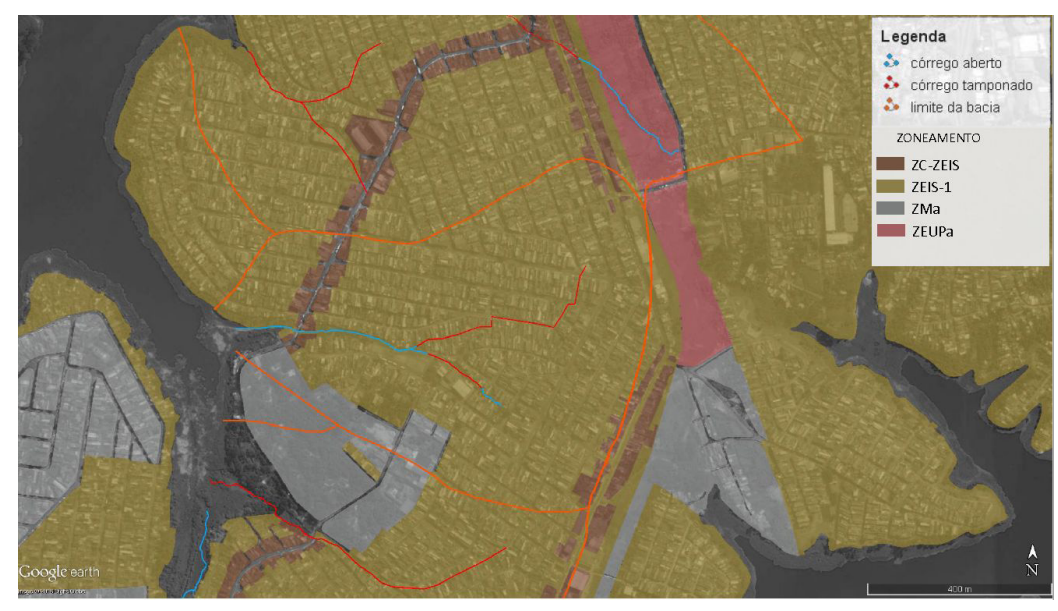

Figura 7 - Novo zoneamento definido para a sub-bacia e arredores. Elaborado a partir de bases de <http://gestaourbana. prefeitura.sp.gov.br>.

Dentro do macrozoneamento ${ }^{4}$ toda a península leste do Ribeirão Cocaia foi definida como macroárea de redução de vulnerabilidade urbana e recuperação ambiental.

Para isso, como pode ser visto no mapa abaixo, praticamente toda a área foi declarada como Zona Especial de Interesse Social (ZEIS), o que em tese permite a regularização fundiária e urbanística dos assentamentos informais e a produção de habitação de interesse social (HIS) destinada à população de baixa renda.

O acesso principal, a estrada Canal de Cocaia, foi definida como Zona Centralidade lindeira à ZEIS (ZC-ZEIS), bem como um trecho da rua Rubens de Oliveira, que acompanha o linhão. Esta zona foi concebida para promover a diversificação de usos, com

\footnotetext{
${ }^{4}$ Consultar página 14 de "Cadernos das Subprefeituras-Capela do Socorro: Material de apoio para revisão participativa dos planos regionais das subprefeituras". Disponível em <http://gestaourbana. prefeitura.sp.gov.br/arquivos-prs/>. Acesso em 02/12/2016.
} 
edificações de altura e adensamento médios e uso não exclusivamente residencial. Pretende-se que sejam subcentros regionais.

Por fim, há uma pequena área próxima à foz do córrego, que abarca a bacia de contribuição difusa mais ao sul, que foi declarada como Zona Mista Ambiental (ZMA), o que impõe parâmetros de parcelamento, uso e ocupação do solo mais restritivos do ponto de vista ambiental.

Anteriormente, cogitou-se a criação de um parque linear compreendendo a orla da represa Billings e as margens de seu córrego tributário ${ }^{5}$.

\section{PROPOSTA DE INTERVENÇÃO}

Como se vê, a sub-bacia escolhida é uma área de grande complexidade ambiental e social. $O$ fato de se localizar às margens da Billings coloca a necessidade de que a proposta de intervenção seja adequada não somente para melhorar as condições de vida dos moradores locais, mas também deve colaborar com a recuperação deste manancial cuja importância estratégica é crescente para o abastecimento de água metropolitano.

Desta maneira, entender e intervir sobre a complexa e degradada hidrologia da área selecionada se impôs como a base real de projeto.

A proposta aqui desenvolvida entende que é possível harmonizar a ocupação consolidada em áreas de manancial com a produção de água de boa qualidade. Sua abordagem é sistêmica e contempla os problemas e potenciais da sub-bacia de maneira integrada. A infraestrutura verde aqui proposta é híbrida, isto é, toma partido de sistemas tecnológicos quando necessário.

\section{O relevo como base para a regeneração das águas urbanas}

O primeiro passo foi entender o "caminho das águas" da nossa sub-bacia. Para isso foi realizada a compartimentação do relevo (ver próxima figura) conforme metodologia

\footnotetext{
${ }^{5}$ Um estudo foi encomendado pela Secretaria do Verde municipal (SVMA) e realizado pelo Laboratório de Habitação e Assentamentos Humanos (LabHab) da Faculdade de Arquitetura e Urbanismo da Universidade de São Paulo (FAUUSP). Ver BONDUKI; FERREIRA, 2006.
} 
proposta por Schutzer $(2004,2012)$ e adaptada por Bonzi $(2015 a, 2015 b)$ para a aplicação da infraestrutura verde em áreas densamente urbanizadas. $O$ terreno foi dividido em quatro compartimentos principais:

Topo de morro (plano e elevado). Compartimento indutor de processos naturais. No que diz respeito ao ciclo hidrológico, nele predomina a infiltração da água da chuva, que percola pelo solo e realiza a recarga do lençol freático e abastecimento das nascentes. É um compartimento que não está sujeito a cheias e inundações.

Encosta de colina. Compartimento transmissor de processos naturais. Dada a declividade, neste setor predomina o escoamento superficial da água da chuva sobre a infiltração. As nascentes surgem em sua base, nos pontos em que ocorre a transição para uma topografia mais suave, de baixíssima declividade.

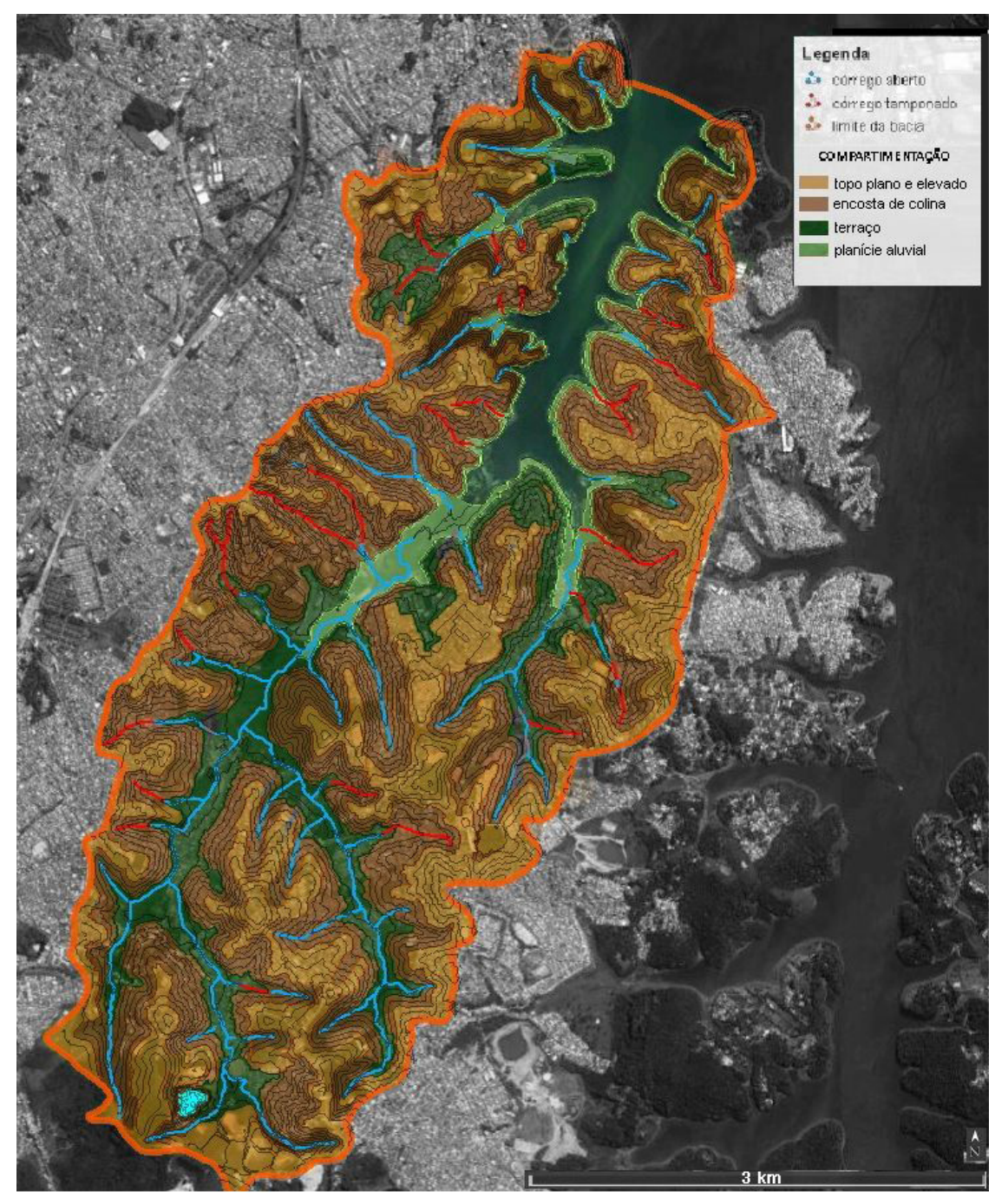

Figura 8 - Compartimentação da bacia do Ribeirão Cocaia, com curvas de nível de 5 em 5 metros. 
Terraços. Sua tabularidade confere capacidade de infiltrar a água da chuva e a altimetria em relação ao nível da represa, apesar da proximidade da linha d'água, o salvaguarda de inundações. É um compartimento receptor de processos naturais, notadamente o escoamento superficial e os sedimentos gerados nas colinas.

Planície aluvial. Esta área está sujeita a inundações e cheias periódicas. Apesar de ser um terreno com pouca declividade, sua proximidade altimétrica do nível do espelho d'água da represa e o lençol freático a poucos metros da superfície diminuem radicalmente a capacidade de infiltração do compartimento. Da mesma maneira, o escoamento superficial se vê limitado ao próprio curso d'água. O processo natural predominante é o armazenamento de água, com predisposição à formação de lagos, brejos e vegetação vigorosa. É um compartimento receptor de água e sedimentos de outros compartimentos.

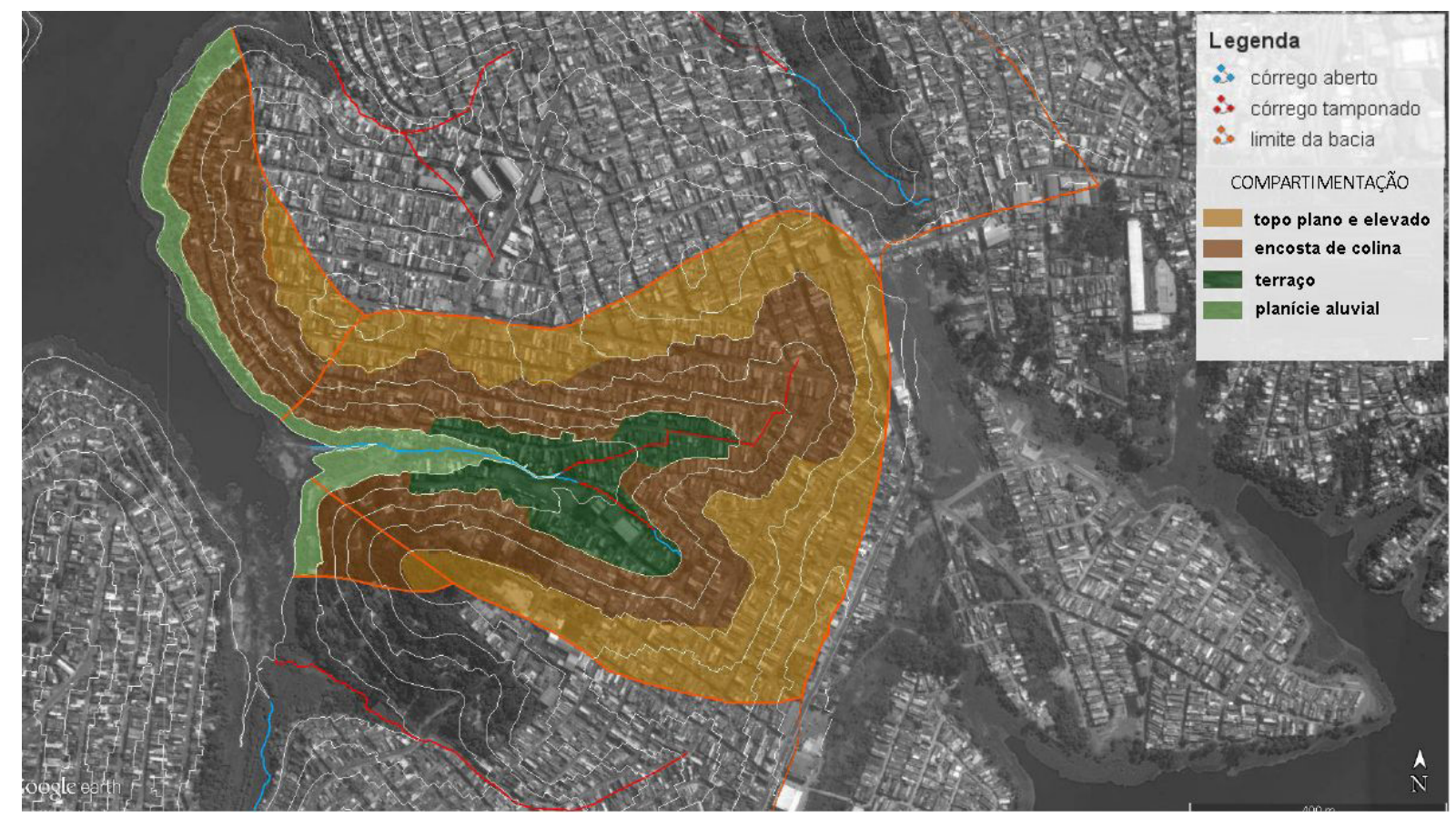

Figura 9 - Compartimentação do relevo da área de projeto, com curvas de nível de 5 em 5 metros.

Pode-se observar que comparativamente à outras bacias hidrográficas da cidade, a do Ribeirão Cocaia possui pouca área de planície aluvial e terraços. Isso se deve à criação do reservatório, que subtraiu 25 metros de amplitude altimétrica junto à foz com o rio Jurubatuba. 


\section{Diretrizes para a intervenção}

Tendo em vista a pesquisa de Bonzi (2015a,2015b), que identifica que tipologias paisagísticas associadas à infraestrutura verde são mais indicadas para cada compartimento do relevo, foi possível conjecturar locais em que a aplicação de cada tipologia obteria o máximo desempenho. O quadro abaixo sintetiza as informações.

\begin{tabular}{|c|c|c|c|c|}
\hline \multirow{2}{*}{ TIPOLOGIA PAISAGÍSTICA } & \multicolumn{4}{|c|}{ COMPARTIMENTO DO RELEVO } \\
\hline & $\begin{array}{c}\text { Topo de morro } \\
\text { (plano e elevado) }\end{array}$ & $\begin{array}{l}\text { Encosta } \\
\text { de colina }\end{array}$ & Terraços & $\begin{array}{c}\text { Planície } \\
\text { aluvial }\end{array}$ \\
\hline Jardim de chuva & $x X$ & - & $X X$ & - \\
\hline Canteiro pluvial com infiltração & $x X$ & - & $x X$ & - \\
\hline Canteiro pluvial sem infiltração & - & $x$ & - & $x x$ \\
\hline Biovaleta & $x x$ & $x$ & $x x$ & $x$ \\
\hline Lagoa pluvial & - & $x$ & - & $X X$ \\
\hline Alagado construído & $X^{(s+)}$ & $x$ & $X^{(s+)}$ & $x x$ \\
\hline Cisterna & $X^{(s+)}$ & $x$ & $X^{(s+)}$ & $X X$ \\
\hline Teto verde & $X^{(s+)}$ & $x$ & $X^{(s+)}$ & $x$ \\
\hline Pavimento drenante & $x X$ & $X^{(+e)}$ & $X^{(+e)}$ & $X^{(+e)}$ \\
\hline
\end{tabular}

Quadro 1 - aplicação das tipologias de acordo com compartimento do relevo. Legenda:

XX máximo desempenho na aplicação da tipologia, com vistas ao incentivo de processos naturais predominantes no compartimento do relevo.

X aplicação compatível, mas com menor desempenho. Tipicamente, a tipologia maneja processos naturais predominantes que se mostram incompatíveis com a ocupação consolidada.

$\mathbf{X}^{(s+)}$ aplicação socialmente positiva, mas que não diz respeito ao objetivo coletivo de manter certa estabilidade da base biofísica da cidade. Aplicação indicada para obtenção de serviços ambientais cuja apropriação é majoritariamente privada.

$\mathbf{X}^{(+e)}$ aplicação que demanda mais estudos para verificação de desempenho no compartimento indicado.

- aplicação incompatível. Tipologia facilita processos naturais que não são os predominantes na compartimento indicado. Desempenho baixo ou nulo, podendo desencadear impactos indesejados. 


\section{Ao se cruzar essas informações com os problemas identificados durante a caracteri-} zação da área de estudo foi possível formular o quadro abaixo que sintetiza os principais desafios a serem enfrentados pela proposta de intervenção, bem como métodos e soluções possíveis.

\begin{tabular}{|c|c|c|c|c|}
\hline DIRETRIZ & IMPORTÂNCIA (FUNÇÃO) & $\begin{array}{l}\text { MÉTODO para } \\
\text { ESPACIALIZAÇÂO }\end{array}$ & AÇÕES & ÁREAS \\
\hline $\begin{array}{l}\text { Aumento de } \\
\text { infiltração do } \\
\text { solo }\end{array}$ & $\begin{array}{l}\text { Melhoria no balanço hídrico e } \\
\text { recarga do aquífero }\end{array}$ & $\begin{array}{l}\text { Compartimentação } \\
\text { do terreno }\end{array}$ & $\begin{array}{l}\text { Implantação de áreas } \\
\text { verdes, jardins de chuva, } \\
\text { canteiros pluviais e } \\
\text { biovaletas }\end{array}$ & $\begin{array}{l}\text { Áreas planas e } \\
\text { terraços }\end{array}$ \\
\hline $\begin{array}{l}\text { Manejo do } \\
\text { escoamento } \\
\text { superficial }\end{array}$ & $\begin{array}{l}\text { Melhoria no balanço hídrico, } \\
\text { proteção de áreas de risco, } \\
\text { diminuição da erosão, } \\
\text { assoreamento e enchentes }\end{array}$ & $\begin{array}{l}\text { Análise do relevo } \\
\text { e da rede de } \\
\text { drenagem existente }\end{array}$ & $\begin{array}{l}\text { Biovaletas, remoção de } \\
\text { moradias em áreas de risco, } \\
\text { terraceamento, canteiros } \\
\text { pluviais de armazenamento }\end{array}$ & $\begin{array}{l}\text { Sistema viário, } \\
\text { drenagem } \\
\text { natural, colinas }\end{array}$ \\
\hline $\begin{array}{l}\text { Requalificação de } \\
\text { córregos }\end{array}$ & $\begin{array}{l}\text { Melhoria no balanço hídrico, uso } \\
\text { das orlas para lazer, aumento da } \\
\text { biodiversidade, identidade local }\end{array}$ & $\begin{array}{l}\text { Compartimentação } \\
\text { do terreno, uso e } \\
\text { ocupação do solo, } \\
\text { mapeamento de } \\
\text { córregos ocultos }\end{array}$ & $\begin{array}{c}\text { Remoção de moradias em } \\
\text { áreas próximas aos cursos } \\
\text { d'água, desenho da orla } \\
\text { fluvial }\end{array}$ & $\begin{array}{l}\text { Orla dos } \\
\text { córregos }\end{array}$ \\
\hline $\begin{array}{l}\text { Tratamento do } \\
\text { esgoto }\end{array}$ & Melhoria da qualidade da água & $\begin{array}{l}\text { Análise do relevo e } \\
\text { da rede de coleta } \\
\text { existente }\end{array}$ & $\begin{array}{l}\text { Micro estações de } \\
\text { tratamento }\end{array}$ & $\begin{array}{l}\text { Universalizar o } \\
\text { atendimento }\end{array}$ \\
\hline $\begin{array}{l}\text { Requalificação da } \\
\text { orla da represa }\end{array}$ & $\begin{array}{l}\text { Melhoria da qualidade da água, } \\
\text { lazer, aumento da biodiversidade, } \\
\text { navegação }\end{array}$ & $\begin{array}{l}\text { Análise do uso e } \\
\text { ocupação do solo, } \\
\text { ortofotos }\end{array}$ & $\begin{array}{l}\text { Remoção de moradias em } \\
\text { áreas próximas à represa, } \\
\text { desenho da orla fluvial }\end{array}$ & $\begin{array}{l}\text { Desapropriação } \\
\text { e áreas ociosas }\end{array}$ \\
\hline $\begin{array}{c}\text { Incentivar } \\
\text { mobilidade fluvial }\end{array}$ & $\begin{array}{l}\text { Vencer longos trajetos impostos } \\
\text { pelo contorno à represa. } \\
\text { Redundância modal }\end{array}$ & $\begin{array}{l}\text { Análise do tecido } \\
\text { urbano e orla da } \\
\text { represa }\end{array}$ & Portos e passarelas & $\begin{array}{l}\text { Represa e } \\
\text { planícies } \\
\text { aluviais }\end{array}$ \\
\hline $\begin{array}{l}\text { Manutenção dos } \\
\text { fundos de braço } \\
\text { da represa }\end{array}$ & $\begin{array}{l}\text { Melhoria da qualidade da água, } \\
\text { aumento do armazenamento, uso } \\
\text { das orlas para lazer e navegação }\end{array}$ & $\begin{array}{l}\text { Análise dos pontos } \\
\text { de assoreamento }\end{array}$ & $\begin{array}{l}\text { Dragagem, criação de } \\
\text { alagados para melhoria da } \\
\text { qualidade da água }\end{array}$ & $\begin{array}{l}\text { Fundo de braço } \\
\text { assoreados }\end{array}$ \\
\hline $\begin{array}{l}\text { Remoção de } \\
\text { população em } \\
\text { área de risco }\end{array}$ & Evitar perdas humanas & $\begin{array}{l}\text { Aplicação do novo } \\
\text { PDE }\end{array}$ & $\begin{array}{l}\text { Produção de habitação de } \\
\text { interesse social }\end{array}$ & $\begin{array}{l}\text { Planícies } \\
\text { aluviais e orla } \\
\text { do córrego }\end{array}$ \\
\hline $\begin{array}{l}\text { Criação de } \\
\text { opções de lazer }\end{array}$ & Saúde, sociabilidade, cultura & $\begin{array}{l}\text { Identificação de } \\
\text { espaços ociosos } \\
\text { e retrofit de áreas } \\
\text { existentes }\end{array}$ & $\begin{array}{l}\text { Criação de novas áreas e } \\
\text { conexão a áreas existentes }\end{array}$ & Toda a área \\
\hline $\begin{array}{l}\text { Complementação } \\
\text { do abastecimento } \\
\text { de água }\end{array}$ & $\begin{array}{c}\text { Segurança hídrica, } \\
\text { conscientização, menor consumo } \\
\text { de água tratada e economia } \\
\text { financeira }\end{array}$ & $\begin{array}{l}\text { Redundância de } \\
\text { fontes, reúso e } \\
\text { reciclagem }\end{array}$ & $\begin{array}{l}\text { Cisternas, reuso de esgoto, } \\
\text { tratamento de escoamento e } \\
\text { águas cinzas por alagados, } \\
\text { microestação de tratamento }\end{array}$ & $\begin{array}{l}\text { Toda a área. } \\
\text { Sobretudo } \\
\text { nas novas } \\
\text { habitações }\end{array}$ \\
\hline
\end{tabular}

Quadro 2 - Principais diretrizes da proposta de intervenção. 


\section{As áreas selecionadas e as intervenções pretendidas}

Para viabilizar essas diretrizes o eixo estruturador da intervenção foi a orla da represa, atualmente ocupada por residências que não contam com tratamento de esgoto adequado e que acabaram por subtrair a possibilidade do restante da população de usufruir essa paisagem, enfraquecendo assim a identidade local.

Sua requalificação se estende à orla do córrego sem nome, que também recebe esgotamento direto em seu corpo d'água embora ainda ofereça, em alguns trechos, conexão visual com o entorno. Para tanto será necessário remover as habitações lindeiras às orlas. Os afetados serão realojados em novas habitações sociais. Tendo em vista o novo zoneamento, foram escolhidas áreas nas zonas previstas (ZC-ZEIS) e próxima a elas para adensamento, junto às vias principais. Calcula-se que nesta operação serão demolidas 360 casas, atingindo $10 \%$ da população da sub-bacia 6 .

Outra ação estratégica para o ciclo hidrológico local é a qualificação do remanescente florestal localizado em um topo de morro ao sul. Dada sua tabularidade e altimetria este é um setor importante para a infiltração da água de chuva que abastece o córrego.

Em relação ao tratamento de esgoto serão utilizadas estações compactas de tratamento (microestações) como alternativa ao atual sistema baseado em estações elevatórias e grandes ETEs. As microestações, capazes de atender até 20.000 pessoas, serão localizadas na orla da represa junto à foz dos córregos, que são os locais de menor altimetria da bacia. Dessa forma, o esgoto de cada sub-bacia é tratado localmente, próximo do local onde é gerado, e a água despoluída que sai das microestações pode ter novos usos.

A nova orla da represa terá em sua parte mais alta uma biovaleta, que conduzirá a água despoluída proveniente das microestações em vazão constante ao longo de todo o dia. A biovaleta também receberá a água da drenagem pluvial existente a fim de interceptar a poluição difusa e os sedimentos carregados pela chuva, servindo assim como uma margem protetora da represa. A partir dessa biovaleta as águas serão conduzidas para alagados construídos, que ocuparão boa parte da orla.

\footnotetext{
${ }^{6}$ Para efeitos comparativos, na reurbanização do Cantinho do Céu foi prevista a realocação de 20 a $30 \%$ da comunidade.
} 
Evidenciando a sinergia que pode ser obtida quando a infraestrutura verde toma partido dos sistemas tecnológicos, esta infraestrutura híbrida irá tratar a poluição difusa e fornecer uma etapa extra no tratamento de esgoto, melhorando a qualidade da água destinada à represa enquanto evita que as plantas dos alagados definhem durante períodos de estiagem prolongada. Os diferentes níveis dos alagados foram projetados para trabalhar com um nível constante de água de $30 \mathrm{~cm}$, podendo comportar outros $25 \mathrm{~cm}$ de água durante os eventos pluviométricos, conforme corte esquemático abaixo.

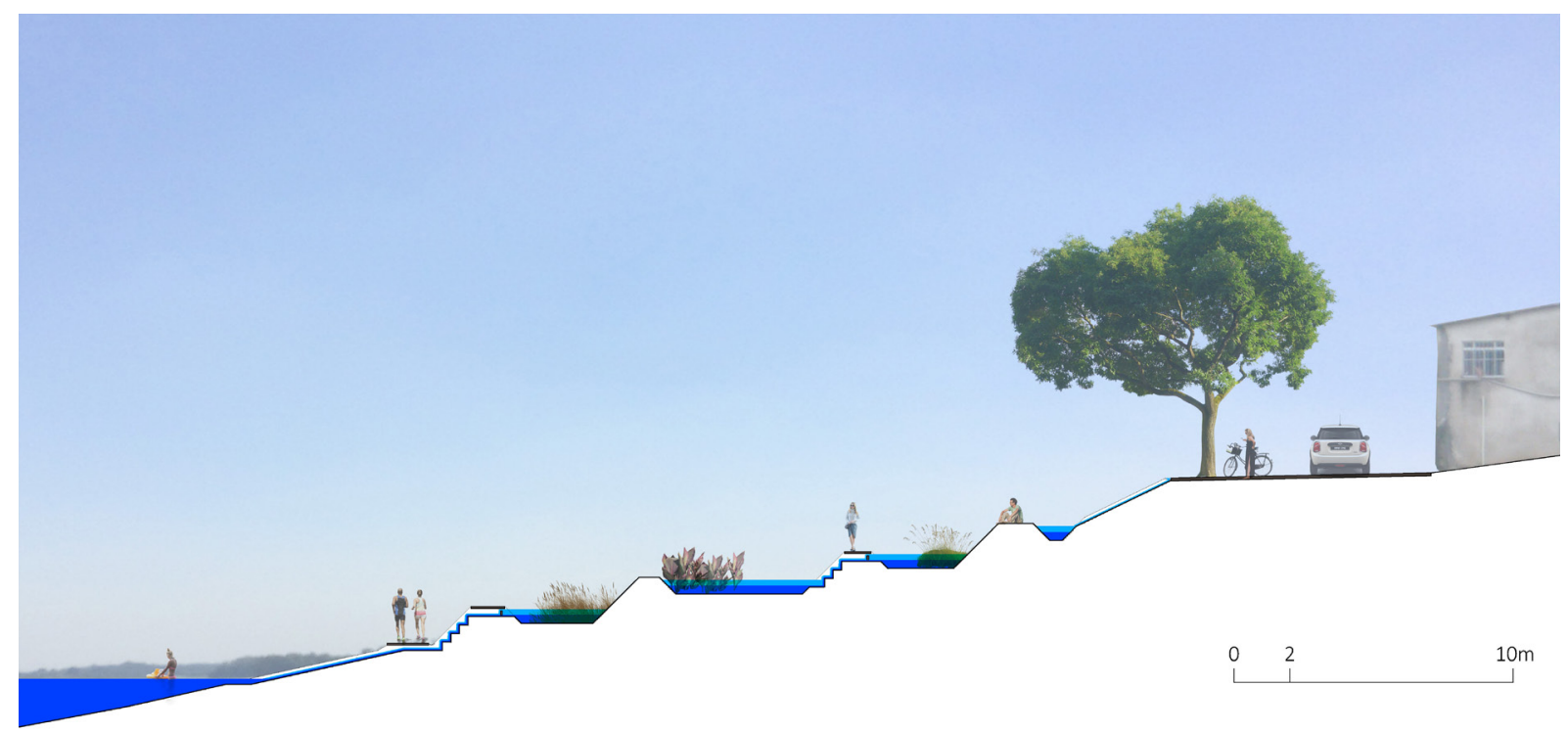

Figura 11 - Corte esquemático da orla requalificada.

A orla será equipada com equipamentos esportivos, mirantes, decks flutuantes, restaurante e Ecoporto, conforme imagem a seguir. Desta maneira, o estudo aqui apresentado se harmoniza com o Hidroanel Metropolitano de São Paulo, proposto pelo Grupo Metrópole Fluvial da FAUUSP.

${ }^{7}$ Conceitualmente os Ecoportos nas represas servem às travessias lacustres de passageiros e ao transporte de resíduos sólidos pré-triados. O projeto do Hidroanel Metropolitano de São Paulo estabelece um sistema de canais navegáveis composto pelos rios Tietê e Pinheiros, e pelas represas Billings e Taiaçupeba, totalizando 170 quilômetros de hidrovias. O Grupo de Pesquisa em Projeto de Arquitetura de Infraestruturas Urbanas Fluviais - Grupo Metrópole Fluvial, pertence ao Laboratório de Projeto do Departamento de Projeto da Faculdade de Arquitetura e Urbanismo da Universidade de São Paulo - FAU USP, coordenado pelo Prof. Alexandre Delijaicov. 


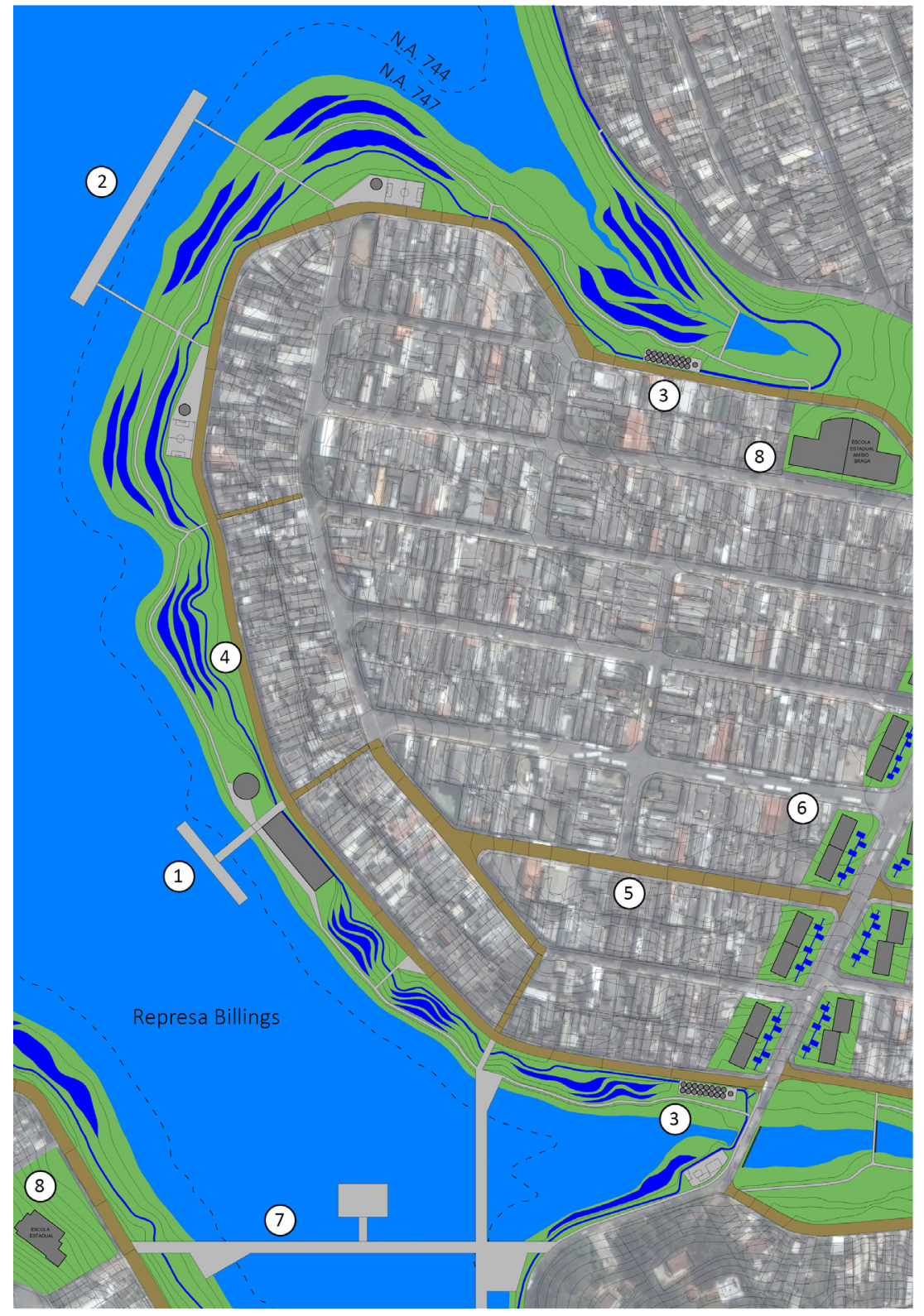

Legenda:

1- Ecoporto e restaurante

2- Deck-praia flutuante

3- Microestação de

tratamento de esgoto

4- Biovaleta e alagados

construídos

5- Caminhos verdes conectando áreas verdes e equipamentos públicos

6- Novos prédios de habitação

7- Passarela conectando as margens

8- Escola pública

Água da represa e dos córregos

Efluentes tratados

$0 \quad 25$ $\stackrel{100 \mathrm{~m}}{\mathrm{~N}}$

Figura 12 - Planta baixa do projeto de requalificação da orla da represa Billings.

Para manejar o escoamento superficial, foram selecionadas ruas para receber canteiros pluviais capazes de interceptar a água da chuva a fim de infiltra-la e/ou evapotranspirá-la, diminuindo assim o volume de água que alcança a represa rapidamente por meio do sistema viário e da rede de drenagem subterrânea.

Foram priorizadas as ruas paralelas às curvas de nível e, portanto, perpendiculares ao sentido do escoamento da água. Essa é a disposição espacial com maior capacidade de interceptar a água da chuva antes dela alcançar a rede de drenagem convencional. 
Também haverá incentivo para a retenção da água dentro dos lotes privados, através de tetos-jardim e pequenas cisternas.

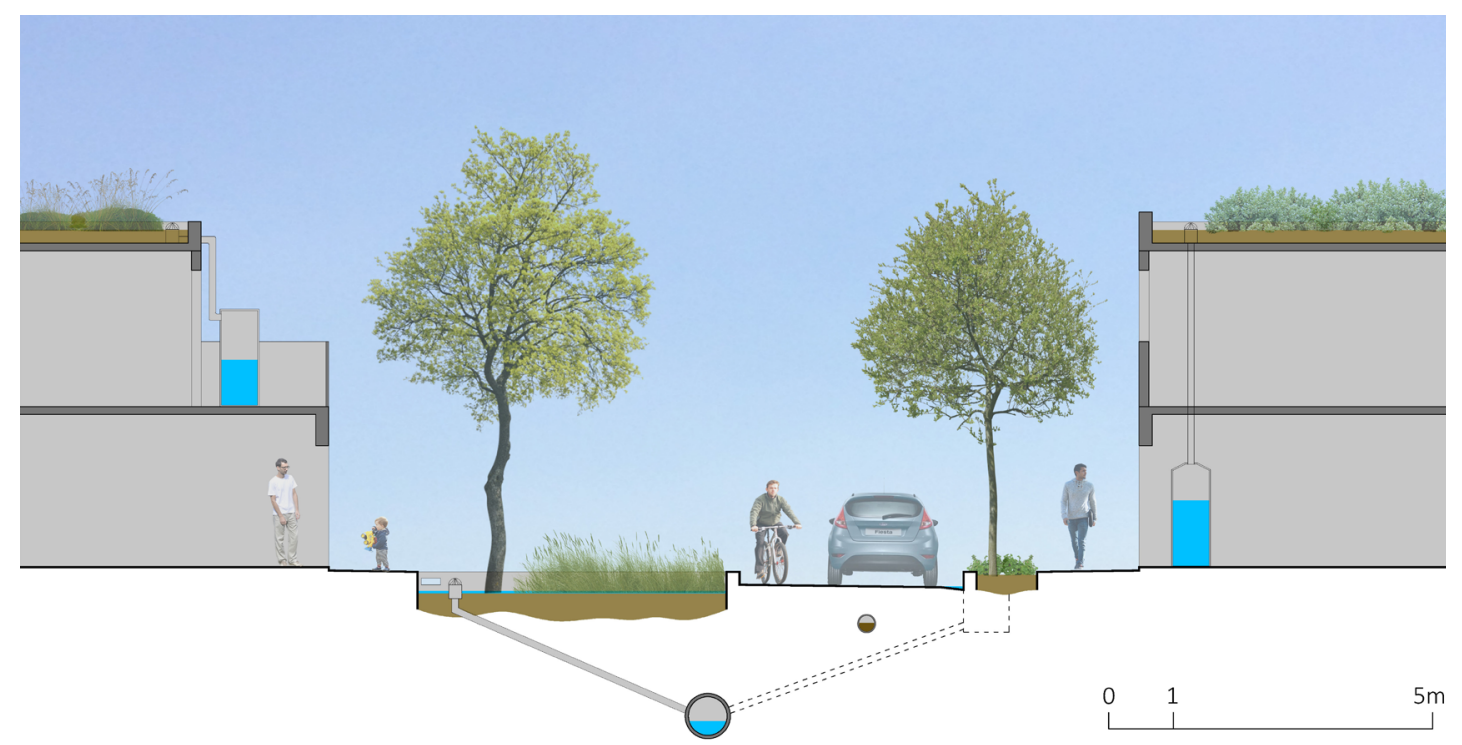

Figura 13 - Corte esquemático da proposta de equipar ruas com canteiros pluviais.

A distribuição dos canteiros será intercalada entre as calçadas, o que irá conferir sinuosidade ao viário, acalmando o tráfego de veículos e incentivando o uso por pedestres e ciclistas, bem como estimulando a permanência na rua como local de encontro e convívio. A figura a seguir aponta as ruas selecionadas.

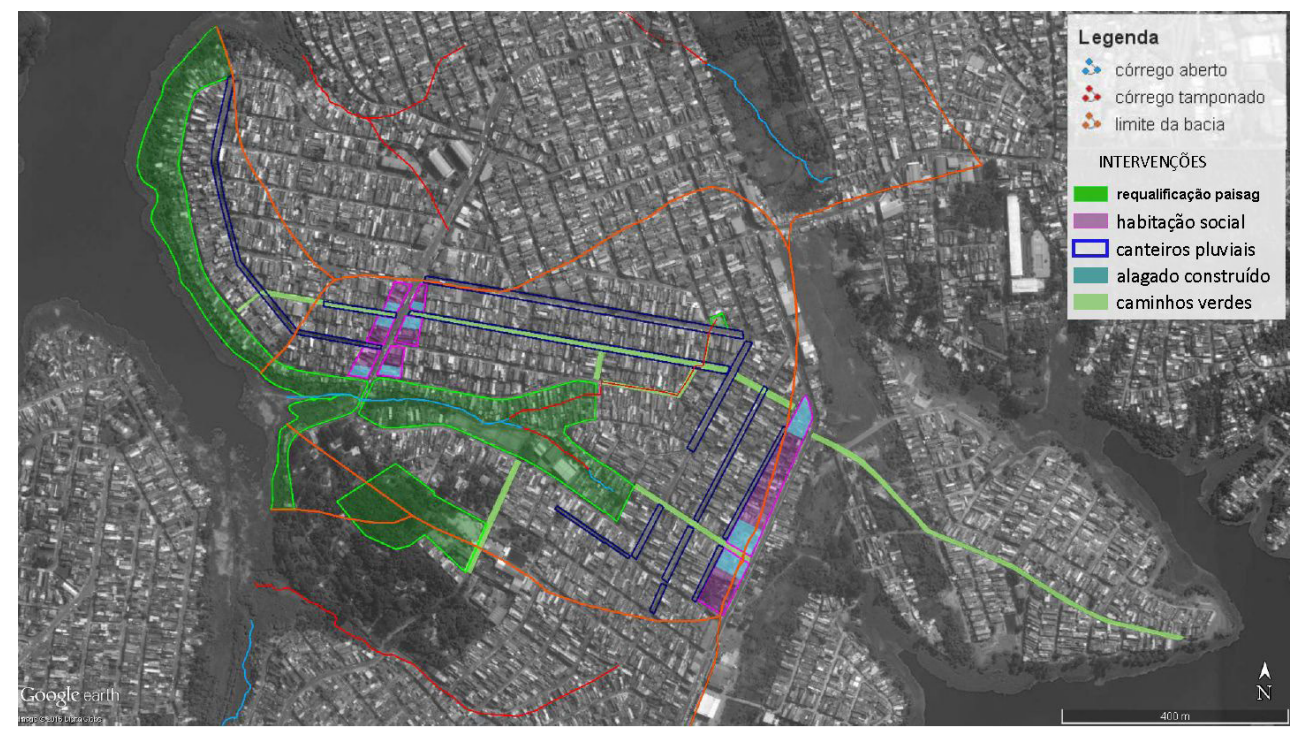

Figura 14 - Em azul a localização das ruas em que é máximo o desempenho de canteiros pluviais. Em verde claro os caminhos verdes que irão conectar os novos parques da região e fazer a conexão da orla da represa com o parque linear do Cantinho do Céu. 
Uma das vias escolhidas foi a rua Vereador José Gomes de Moraes Neto. Ela terá um tratamento diferenciado, pois também deverá cumprir a função de conectar a orla requalificada ao parque linear do Cantinho do Céu, conforme mapa anterior.

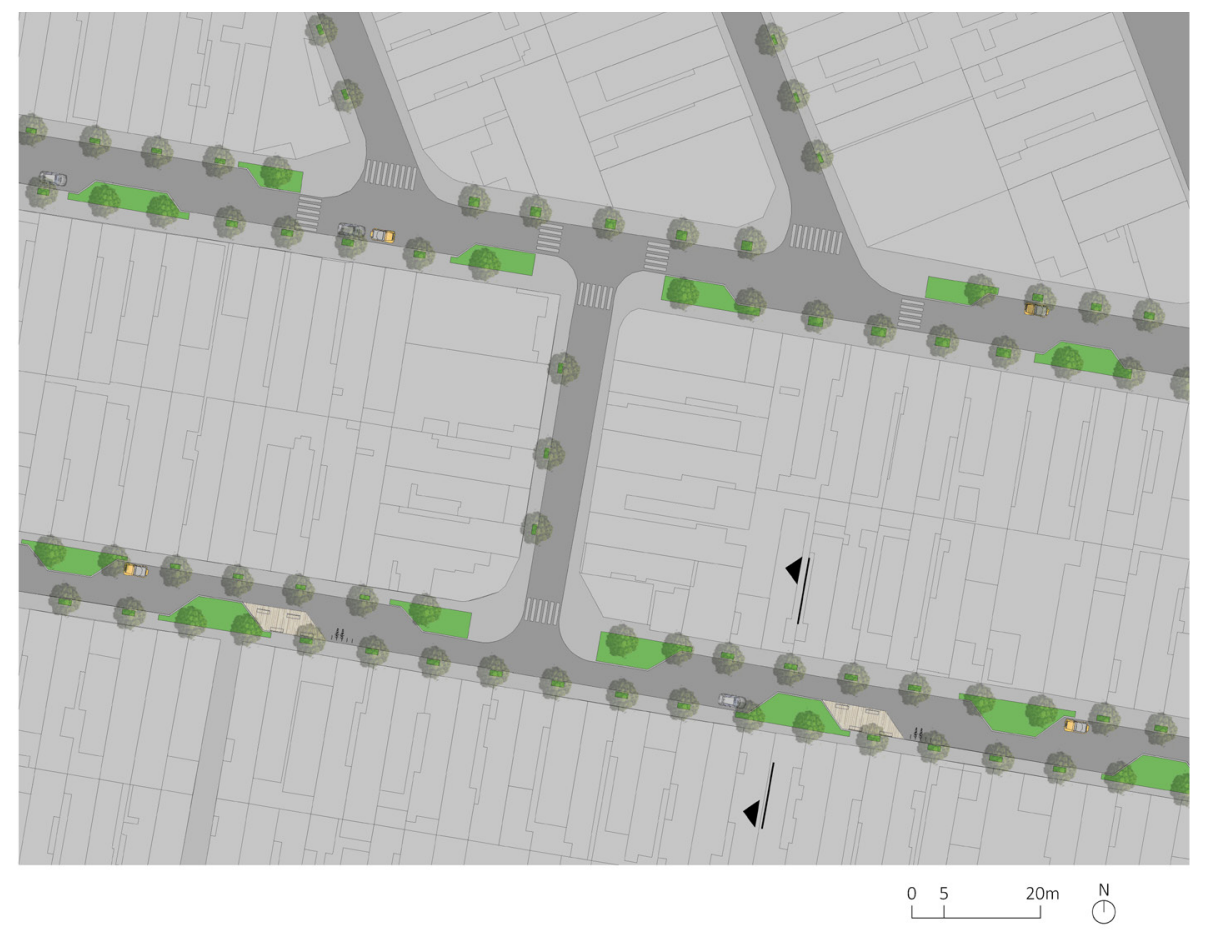

Figura 15 - Planta baixa mostra o tratamento de ruas que receberão canteiros pluviais. A via mais ao sul é a rua Vereador José Gomes de Moraes Neto

A planta baixa acima revela que além do maior porte dos canteiros pluviais, parte do viário será subtraído para criar áreas de estar e estacionamentos para bicicletas. $\mathrm{A}$ arborização será reforçada a fim de criar a sensação de que é possível se locomover da orla da represa até o parque linear do Cantinho do Céu dentro de uma área verde contínua. Lombofaixas reforçarão a prioridade do pedestre neste caminho verde.

Nas áreas desapropriadas para fins de habitação social estão previstos alagados construídos, como evidenciado na próxima imagem. Eles desempenharão múltiplas funções $^{8}$ : tratamento das águas cinzas geradas pelas edificações, manejo do escoamento superficial gerado nos terrenos e adjacências, fornecimento de água não potável para irrigação dos jardins e limpeza de calçadas e áreas comuns dos con-

\footnotetext{
${ }^{8}$ No caso das HIS propostas no eixo da rua Rubens de Oliveira (e continuando na rua Pedro Escobar), os alagados aí propostos irão colaborar com a recarga de aquíferos já que estarão localizadas em áreas planas e elevadas, com grande capacidade de infiltração.
} 
domínios. Integrarão as áreas verdes dos condomínios, sem muros, de modo a criar espaços de uso público. No caso das habitações dispostas ao longo do ZC-ZEIS da estrada Canal de Cocaia, esses jardins com alagados criarão uma conexão espacial qualificada entre os novos parques da região, conectando também as escolas localizadas junto aos córregos.

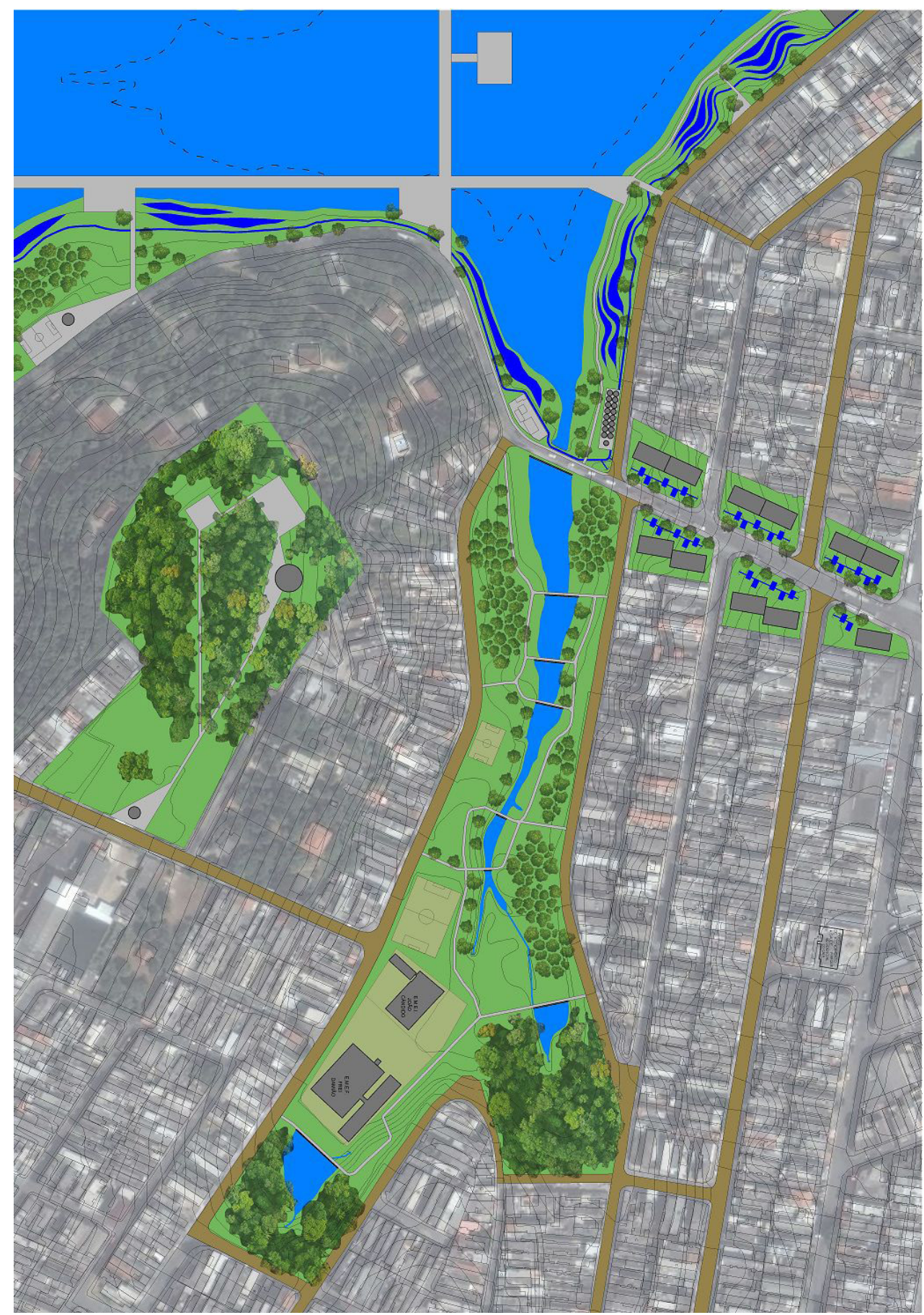

Figura 16 - Planta baixa das novas habitações sociais, orlas requalificadas do córrego e da represa e zona de infiltração com mirante, ao sul. 
Pretende-se que as orlas requalificadas sejam conectadas às penínsulas vizinhas por passarelas oferecendo assim maior mobilidade local, como pode ser visto na imagem acima.

A orla do córrego afluente da represa será modificada de modo a constituir espaços de lazer para a população enquanto resgata a capacidade que a mata ciliar suprimida tinha de reter sedimentos e carga orgânica trazida pelo escoamento superficial da água da chuva. Para isso serão realizados barramentos no leito do córrego, aumentando o espelho d'água, o que criará nichos para o estabelecimento de vegetação aquática e consequente aumento da capacidade de filtrar poluentes.

Tendo em vista que serão mantidas duas escolas localizadas na margem esquerda do córrego (EMEI João Candido e EMEF Frei Damião), foram propostos espaços bastante diferenciados entre si, que criam uma variedade de ecossistemas com grande potencial educativo: além do próprio córrego, que terá acessos à sua margem, pequenos lagos nas nascentes de ambos os braços do córrego, seguidos à jusante por reflorestamento com espécies de mata atlântica, pomar, horta, mata ciliar e o próprio ambiente de brejo que surgirá com o barramento do córrego, conforme imagem acima.

\section{CONSIDERAÇÕES FINAIS}

As áreas de manancial estão entre as mais complexas e difíceis de se intervir. A aplicação conceitual da infraestrutura verde no recorte espacial selecionado confirma que a noção de infraestrutura verde é capaz de conciliar a ocupação humana de área de manancial com a manutenção e a melhoria de processos naturais fundamentais para a produção de água de boa qualidade.

A leitura estratégica do relevo, com a identificação dos processos que ocorrem em cada compartimento, e a escolha coerente das tipologias paisagísticas de acordo com esses processos, confere à infraestrutura verde certa racionalidade que frequentemente falta à intervenção urbana e ao planejamento da paisagem.

Embora a noção de infraestrutura verde seja amplamente aceita nos campos da arquitetura da paisagem e do urbanismo, as suas aplicações se limitam a planos de drenagem urbana e de proteção da biodiversidade. 
Neste sentido, o presente trabalho aporta com uma importante colaboração ao realizar um esforço teórico e projetual de aplicar a infraestrutura verde à temática do abastecimento de água potável.

É uma abordagem que, dada a característica fractal das bacias hidrográficas, torna possível replicar, ao menos parcialmente, as soluções encontradas ao seu entorno.

Entendemos que a proposta apresentada de requalificação da orla lacustre como uma faixa úmida que universaliza o tratamento de esgoto e filtra a poluição difusa carreada pelo escoamento superficial aumentaria consideravelmente a segurança hídrica metropolitana se fosse estendida a todo o perímetro dos reservatórios localizados em área urbana, como é o caso de partes da Billings e da Guarapiranga.

\section{REFERÊNCIAS}

BONDUKI, N; FERREIRA, J.S. Caracterização de áreas de estudo para implantação de Parques Lineares. Projeto "Pesquisa e análise de aplicação de instrumentos em planejamento urbano ambiental no município de São Paulo”, 2006.

BONZI, Ramón. S. Andar sobre Água Preta: a aplicação da Infraestrutura Verde em áreas densamente urbanizadas. Dissertação (Mestrado em Arquitetura e Urbanismo). FAUUSP, 2015a.

O Zoneamento Ambiental Geomorfológico como método para planejar a Infraestrutura Verde em áreas densamente urbanizadas. Revista LABVERDE, v. 1, n. 10, p. 104-132, 2015b.

CAPOBIANCO, João Paulo Ribeiro; WHATELY, Marussia. Billings 2000: ameaças e perspectivas para o maior reservatório de água da região metropolitana de São Paulo: relatório do diagnóstico socioambiental participativo da bacia hidrográfica da Billings no período 1989-99. Instituto Socioambiental, 2002.

IAMAMURA, R. B. R. Higiene pessoal fora da residência: os sanitários públicos na área central da cidade de São Paulo. Dissertação (Mestrado em Urbanismo). Campinas: PUC, 2006. 
SÃO PAULO (Cidade). Secretaria de Desenvolvimento Urbano. Cadernos das Subprefeituras-Capela do Socorro: Material de apoio para revisão participativa dos planos regionais das subprefeituras. São Paulo: 2016.

SCHUTZER, José Guilherme. Cidade e meio ambiente: a apropriação do relevo no desenho ambiental urbano. Dissertação (Mestrado em Arquitetura e Urbanismo). FAUUSP, 2004.

Cidade e meio ambiente: a apropriação do relevo no desenho ambiental urbano. São Paulo: Edusp, 2012.

SILVA, Daniel Clemente Vieira Rêgo da. Toxicidade da água e sedimento dos reservatórios Guarapiranga, Billings e Paiva Castro, na região metropolitana de São Paulo - SP. 2013. Dissertação (Mestrado em Ecologia: Ecossistemas Terrestres e Aquáticos) - Instituto de Biociências, Universidade de São Paulo, 2013.

SILVA, R. T.; PORTO, M. F. do Amaral. Gestão urbana e gestão das águas: caminhos da integração. Estudos avançados, v. 17, n. 47, p. 129-145, 2003. 